\title{
Chemical polymorphism of the essential oils from populations of Thymus caespititius grown on the island S. Jorge (Azores)
}

\author{
S.I. Pereira ${ }^{\text {a }}$, P.A.G. Santos ${ }^{\text {a }}$, J.G. Barroso ${ }^{\text {a,* }}{ }^{\text {, A.C. Figueiredo }}{ }^{\text {a }}$, L.G. Pedro ${ }^{\text {a }}$, \\ L.R. Salgueiro ${ }^{b}$, S.G. Deans ${ }^{\text {c }}$, J.J.C. Scheffer ${ }^{d}$ \\ ${ }^{a}$ Centro de Biotecnologia Vegetal, Departamento de Biologia Vegetal, Faculdade de Ciências de Lisboa, Bloco C2, Campo Grande, 1749-016 Lisbon, Portugal \\ ${ }^{\mathrm{b}}$ Laboratório de Farmacognosia, Faculdade de Farmácia, Universidade de Coimbra, Rua do Norte, 3000 Coimbra, Portugal \\ ${ }^{\mathrm{c}}$ Aromatic and Medicinal Plant Group, Food Science and Technology Department, SAC, Auchincruive, Ayr KA6 5HW, Scotland, UK \\ ${ }^{\mathrm{d}}$ Division of Pharmacognosy, LACDR, Leiden University, Gorlaeus Laboratories, PO Box 9502, 2300 RA Leiden, The Netherlands
}

Received 4 May 2000; received in revised form 4 July 2000

\begin{abstract}
The compositions of the essential oils obtained from ten populations of Thymus caespititius grown on S. Jorge (Azores) were studied by GC and GC-MS. All the oils analysed were dominated by their monoterpene fraction (69-91\%). The sesquiterpene fraction was rather small (4-17\%) and consisted mainly of oxygen-containing compounds (3-13\%). Enantiomeric ratio of sabinene and $\alpha$-terpineol was investigated in the oils from some populations. $(+)$-Sabinene was detected with high enatiomeric purity $(96-$ $99 \%)$. Although $(+)-\alpha$ terpineol was the predominant enantiomer, its purity varied considerably $(66-97 \%)$. Cluster analysis of all identified components grouped the oils into four main clusters that corresponded with their major components: $\alpha$-terpineol (43$68 \%$ ), carvacrol (32-52\%), thymol (44-58\%) and sabinene (41\%). The essential oil from Th. caespititius showed a clear chemical polymorphism, that was particularly evident among four populations growing along a $200 \mathrm{~m}$ distance at Pico Verde. (C) 2000 Elsevier Science Ltd. All rights reserved.
\end{abstract}

Keywords: Thymus caespirtitius; Lamiaceae; Essential oil; Chemical polymorphism; Enantiomers; Chemotypes; Azores

\section{Introduction}

Thymus caespititius Brot. is a low creeping shrub, with pink purplish or whitish inflorescences, that belongs to the section Micantes of the genus Thymus. Being characteristic of Atlantic wet areas, Th. caespititius is an endemic plant of the NW Iberian Peninsula and of the Madeiran and Azorean archipelagos (Fernandes Costa, 1945; Salgueiro, 1994). 'Erva-úrsula', as it is commonly known in the Azores, is the only representative of the genus in this archipelago, and it is one of the few Azorean plants with an altitude range extending from sea level to the highest altitudes as on Pico (Sjögren, 1984; Pena and Cabral, 1997). Th. caespititus is also one of the first colonizing plants on various types of substrates, and consequently it is considered as an indicator of recent vegetation developments (Sjögren, 1984).

\footnotetext{
* Corresponding author.

E-mail address: acsf@fc.ul.pt (J.G. Barroso).
}

Previous studies on essential oils obtained from populations of Th. caespititius collected either in the Portuguese mainland (Fernandes Costa, 1945, 1975; Salgueiro, 1994; Salgueiro et al., 1997) or on the Azorean islands Pico (Salgueiro et al., 1997) and Faial (Pereira et at., 1999a) showed significant differences in their compositions.

As a part of our screening programme of the aromatic flora of Macaronesia, we report in this paper on the chemical polymorphism of the essential oils obtained from ten populations of Th. caespititius grown on S. Jorge.

\section{Results and discussion}

The ten populations of Thymus caespititius studied were collected in seven different sites on the island $\mathrm{S}$. Jorge, in an altitude range from $130 \mathrm{~m}$ (population SJ8) to $900 \mathrm{~m}$ (populations SJ1-SJ4), as indicated in Fig. 1.

The oils were obtained in yields of $0.4-0.7 \%(\mathrm{v} / \mathrm{w})$, and 34-40 components were identified in the ten oil 


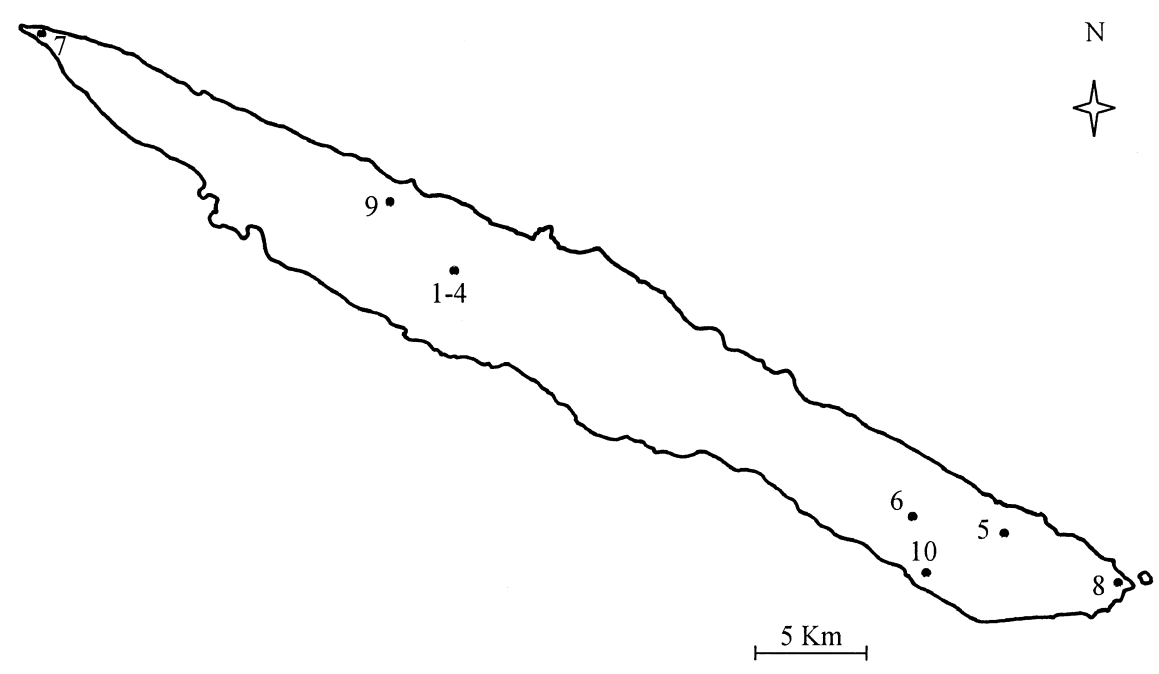

Fig. 1. Distribution of ten populations of Thymus caespititius studied, according to their collection sites on the island S. Jorge. Populations SJ1-SJ4: Pico Verde, 900 m; Population SJ5: Cume dos Arrebentões, 600 m; Population SJ6: Serra do Topo, 700 m; Population SJ7: Farol dos Rosais, 300 m; Population SJ8: Ponta do Topo, 130 m; Population SJ9: Pico da Ponta Furada, 560 m; Population SJ10: Fajã de S. João, 300 m.

samples, amounting to a total percentage of $85-96 \%$. The identified components and their percentages are given in Table 1, where the components are listed in order of their elution from the DB-1 column.

The monoterpene fraction (69-91\%) was dominant in all oils analysed, although with remarkable differences concerning the main component; $\alpha$-terpineol was the major component of the oils from the populations SJ5, SJ6 and SJ1Ø (43, 47 and 68\%, respectively), whereas carvacrol was the main component of those from the populations SJ2, SJ8 and SJ9 (52, 36 and 32\%, respectively), and thymol of those from the populations $\mathrm{SJ} 1$, SJ4 and SJ7 (58, 45 and 44\%, respectively). Although the essential oil from population SJ3 contained also a considerable amount of carvacrol (17\%), it was dominated by sabinene $(41 \%)$.

The rather small sesquiterpene fraction, ranging from 4 to $17 \%$, was dominated by oxygen-containing sesquiterpenes $(3-13 \%)$. trans-Dihydroagarofuran, $\gamma$-cadinene, kessane, T-cadinol, $\alpha$-cadinol and intermedeol were the main components ( $>1 \%$ ) of this fraction, but in variable amounts, depending on the population under study. As to the dominant components of this fraction, the oils from the populations grown on S. Jorge were quantitatively and qualitatively similar to that reported for populations grown on Pico (Salgueiro et al., 1997) and Faial (Pereira et at., 1999a), but differed - to some extent - from the oils of the Portuguese mainland populations (Salgueiro et al., 1997).

Cluster analysis of all identified components grouped the oils from the ten populations into four main clusters, that corresponded with their major components: $\alpha$-terpineol, carvacrol, thymol and sabinene.

The cluster formed by the populations SJ5, SJ6 and SJ10 (Fig. 2) possessed $\alpha$-terpineol-rich oils, like the previously studied populations grown in the Portuguese mainland (Salgueiro et al., 1997). However, the oils from the latter populations contained lower levels of $\alpha$-terpineol $(31-41 \%)$ than those isolated from the populations of S. Jorge (43-68\%).

The cluster formed by the populations SJ2, SJ8 and SJ9 had carvacrol as the main oil component (32-52\%). The compositions of these oils were quite similar to that reported for populations grown on Pico (Salgueiro et al., 1997) and on Faial (Pereira et al., 1999a).

The populations SJ1, SJ4 and SJ7 formed another cluster with phenol-type essential oils, like the previous cluster, but being dominated by thymol, the concentration of which ranged from 44 to $58 \%$.

The last cluster was formed by the oil from population $\mathrm{SJ} 3$, that was dominated by monoterpene hydrocarbons (54\%), sabinene being the main component (41\%).

The chemical variability found for the compositions of the essential oils from Th. caespititius grown on S. Jorge is consistent with the high chemical polymorphism reported earlier for this genus (Mártonfi et al., 1994; Salgueiro, 1994). This polymorphism can occur over very short distances, persisting in time through a low migration rate of genes resulting from the predominance of short-distance pollination by bees (Boira and Blanquer, 1998). In fact, this variability was especially high among the populations SJ1-SJ4, growing over a $200 \mathrm{~m}$ distance on the same slope of Pico Verde.

Comparing the results obtained for our plant material collected in 1999, with those recorded for samples collected, at the same sites, during the flowering phase of the plant in 1998 (Pereira et al., 1999b), no remarkable differences were seen in the compositions of the oils from the populations growing on Cume dos Arrebentões (population SJ5), Serra do Topo (population SJ6), Pico da Ponta Furada (population SJ9) and Fajã de S. João (population SJ10). In contrast, the compositions of the 
Table 1

Percentage composition of the essential oils isolated from the aerial parts, collected during the flowering phase, from ten populations of Thymus caespititius grown on S. Jorge; collection sites of the populations are given in Fig. 1

\begin{tabular}{|c|c|c|c|c|c|c|c|c|c|c|c|}
\hline \multirow[b]{2}{*}{ Components } & \multirow[b]{2}{*}{$\mathrm{RI}^{\mathrm{a}}$} & \multicolumn{10}{|c|}{ Populations } \\
\hline & & SJ1 & SJ2 & SJ3 & SJ4 & SJ5 & SJ6 & SJ7 & SJ8 & SJ9 & SJ10 \\
\hline$\alpha$-Thujene & 924 & 1.5 & 2.7 & 2.5 & 2.6 & 0.9 & 0.9 & 2.2 & 1.3 & 2.1 & 0.2 \\
\hline$\alpha$-Pinene & 930 & 0.3 & 0.9 & 0.3 & 0.6 & 0.3 & 0.3 & 0.6 & 0.4 & 0.7 & 0.1 \\
\hline Camphene & 938 & 0.1 & 0.1 & 0.1 & 0.1 & $t^{c}$ & $\mathrm{t}$ & 0.1 & $\mathrm{t}$ & 0.1 & $\mathrm{t}$ \\
\hline Sabinene & 958 & 0.1 & 2.3 & 40.9 & 4.2 & 2.1 & 0.6 & 0.1 & 0.4 & 0.1 & 0.9 \\
\hline Oct-1-en-3-ol & 961 & & & & & & & 0.1 & 0.1 & 0.1 & \\
\hline$\beta$-Pinene & 963 & 0.4 & 0.5 & 0.1 & 0.2 & 0.5 & 0.3 & 0.7 & 0.5 & 0.7 & 0.2 \\
\hline Dehydro-1,8- cineole & 974 & & & & & 0.1 & 0.1 & $\mathrm{t}$ & 0.1 & $\mathrm{t}$ & 0.1 \\
\hline$\beta$-Myrcene & 975 & & & & & 0.1 & 0.1 & & 0.3 & & \\
\hline$\alpha$-Phellandrene & 995 & 0.2 & 0.1 & 0.1 & 0.3 & 0.1 & 0.1 & 0.2 & 0.1 & 0.2 & $\mathrm{t}$ \\
\hline$\Delta 3$-Carene & 1000 & 0.1 & 0.1 & $\mathrm{t}$ & 0.1 & $\mathrm{t}$ & $\mathrm{t}$ & 0.1 & $\mathrm{t}$ & 0.1 & $\mathrm{t}$ \\
\hline$\alpha$-Terpinene & 1002 & 1.6 & 1.0 & 2.3 & 2.8 & 1.3 & 1.3 & 1.3 & 0.6 & 1.0 & 0.3 \\
\hline$p$-Cymene & 1003 & 8.4 & 5.3 & 2.5 & 9.3 & 3.0 & 4.5 & 9.4 & 4.0 & 7.3 & 0.5 \\
\hline$\beta$-Phellandrene & 1005 & 0.2 & 0.2 & 0.3 & 0.4 & 0.3 & 0.2 & 0.2 & 0.1 & 0.2 & 0.1 \\
\hline Limonene & 1009 & 0.3 & 0.2 & 0.2 & 0.3 & 1.4 & 1.0 & 0.6 & 0.5 & 0.5 & 0.9 \\
\hline$\gamma$-Terpinene & 1035 & 3.4 & 2.2 & 4.1 & 5.6 & 8.1 & 8.4 & 4.0 & 2.9 & 3.3 & 0.7 \\
\hline trans-Sabinene hydrate & 1037 & & 0.1 & & & & & & & & \\
\hline Terpinolene & 1064 & 0.1 & 0.2 & 0.7 & 0.5 & 0.4 & 0.3 & 0.2 & 0.2 & 0.2 & 0.3 \\
\hline cis-Sabinene hydrate & 1066 & & $\mathrm{t}$ & & & & & & & & \\
\hline Linalool & 1074 & & & & & 0.2 & 0.2 & 0.1 & 0.1 & & 0.2 \\
\hline Oct-1-en-3-yl acetate & 1086 & 0.3 & 0.4 & 0.2 & 0.4 & 0.2 & 0.1 & 0.3 & 0.2 & 0.6 & $\mathrm{t}$ \\
\hline trans-p-Menth-2-en-1-ol & 1095 & & $\mathrm{t}$ & & & & & & & & \\
\hline Isomenthone & 1126 & & & & & 0.1 & & & & & \\
\hline Borneol & 1134 & $\mathrm{t}$ & & & $\mathrm{t}$ & & & 0.1 & 0.1 & 0.1 & \\
\hline Terpinen-4-ol & 1148 & 0.7 & 1.1 & 5.7 & 3.7 & 0.9 & 0.8 & 0.8 & 0.7 & 0.9 & 0.9 \\
\hline$\alpha$-Terpineol & 1159 & $\mathbf{t}$ & 1.4 & 0.2 & 0.2 & 43.0 & 46.6 & 10.4 & 15.3 & 6.4 & 68.3 \\
\hline Carvone & 1206 & & & 0.1 & 0.1 & & & $\mathrm{t}$ & 0.1 & 0.1 & $\mathrm{t}$ \\
\hline Carvacrol methyl ether & 1224 & & & & $\mathrm{t}$ & & & $\mathrm{t}$ & & & \\
\hline Thymol & 1275 & 57.9 & 2.5 & 4.3 & 44.5 & 7.0 & 8.4 & 44.4 & 1.4 & 19.8 & 3.0 \\
\hline Carvacrol & 1286 & 3.5 & 52.3 & 17.2 & 2.5 & 1.5 & 2.3 & 2.9 & 35.9 & 31.5 & 0.5 \\
\hline Thymyl acetate & 1330 & 10.5 & 0.5 & 0.5 & 12.3 & 0.9 & 1.3 & 3.7 & 0.1 & 3.7 & 0.4 \\
\hline Carvacryl acetate & 1348 & 0.5 & 5.3 & 2.6 & 0.5 & 0.6 & 0.1 & 0.2 & 3.9 & 4.4 & $\mathrm{t}$ \\
\hline$\beta$-Elemene & 1388 & & & 0.2 & 0.1 & 0.2 & 0.8 & 0.1 & 0.1 & 0.1 & $\mathrm{t}$ \\
\hline$\beta$-Caryophyllene & 1414 & $\mathrm{t}$ & $\mathrm{t}$ & $\mathrm{t}$ & $\mathrm{t}$ & 0.1 & $\mathrm{t}$ & 0.1 & $\mathrm{t}$ & 0.1 & $\mathrm{t}$ \\
\hline allo-Aromadendrene & 1454 & 0.2 & 0.3 & 0.2 & 0.2 & 0.4 & 0.2 & & 0.5 & 0.5 & 0.4 \\
\hline Germacrene- D & 1474 & & $\mathrm{t}$ & & & $\mathrm{t}$ & 0.6 & & & & 0.2 \\
\hline trans-Dihydroagarofuran & 1489 & 0.7 & 1.8 & 1.7 & 1.5 & 3.4 & 1.9 & 0.5 & 3.2 & 1.5 & 3.5 \\
\hline$\alpha$-Muurolene & 1494 & $\mathrm{t}$ & $\mathrm{t}$ & & 0.1 & 0.1 & & 0.1 & & 0.1 & \\
\hline$\gamma$-Cadinene & 1496 & 0.3 & 0.6 & 0.4 & 0.3 & 0.9 & 1.6 & 1.7 & 1.7 & 1.2 & 1.2 \\
\hline Calamenene & 1505 & 0.1 & 0.1 & $\mathrm{t}$ & $\mathrm{t}$ & 0.1 & 0.1 & 0.3 & 0.3 & 0.3 & $\mathrm{t}$ \\
\hline$\delta$-Cadinene & 1505 & 0.3 & 0.3 & 0.2 & 0.3 & 0.6 & 0.5 & 0.7 & 0.3 & 0.5 & 0.3 \\
\hline Kessane $^{\mathrm{b}}$ & 1517 & 0.3 & 0.9 & 0.8 & 0.7 & 1.4 & 0.8 & 0.1 & 1.5 & 0.6 & 1.7 \\
\hline$\alpha$-Cadinene & 1529 & & & $\mathrm{t}$ & & $\mathrm{t}$ & 0.1 & & 0.1 & $\mathrm{t}$ & $\mathrm{t}$ \\
\hline Elemol & 1530 & 0.3 & 0.1 & $\mathrm{t}$ & & 0.1 & 0.1 & 0.5 & 0.2 & 0.3 & 0.1 \\
\hline epi-Cubenol & 1600 & & & & & & & 0.6 & & & \\
\hline T-Cadinol & 1616 & 1.3 & & 1.3 & 0.7 & 3.0 & 5.2 & 5.1 & 7.5 & 3.3 & 3.8 \\
\hline$\delta$-Cadinol & 1618 & & 2.2 & $\mathrm{t}$ & $\mathrm{t}$ & $\mathrm{t}$ & & & & & \\
\hline$\beta$-Eudesmol & 1620 & 0.2 & $\mathrm{t}$ & & & & & 0.8 & 0.2 & 0.3 & 0.1 \\
\hline$\alpha$-Cadinol & 1626 & 0.3 & 1.2 & & & 0.9 & 2.4 & 0.9 & 1.8 & 1.6 & 0.5 \\
\hline Intermedeol & 1626 & 0.3 & & 2.2 & 0.7 & 0.9 & & 0.9 & & & \\
\hline Identified components (\%) & & 94.4 & & 91.9 & 95.8 & 85.1 & 92.2 & 95.1 & 86.7 & 94.5 & 89.4 \\
\hline \multicolumn{12}{|l|}{ Grouped components } \\
\hline Monoterpene hydrocarbons & & 16.7 & 15.8 & 54.1 & 27.0 & 18.5 & 18.0 & 19.7 & 11.3 & 16.5 & 4.2 \\
\hline Oxygen-containing monoterpenes & & 73.1 & 63.2 & 30.6 & 63.8 & 54.3 & 59.8 & 62.6 & 57.7 & 66.9 & 73.4 \\
\hline Sesquiterpene hydrocarbons & & 1.2 & 2.2 & 1.8 & 1.7 & 3.8 & 4.7 & 3.1 & 4.5 & 3.4 & 3.8 \\
\hline Oxygen-containing sesquiterpenes & & 3.1 & 5.3 & 5.2 & 2.9 & 8.3 & 9.6 & 9.3 & 12.9 & 7.0 & 8.0 \\
\hline Others & & 0.3 & 0.4 & 0.2 & 0.4 & 0.2 & 0.1 & 0.4 & 0.3 & 0.7 & $\mathrm{t}$ \\
\hline Oil yield $(\%, v / w)$ & & 0.7 & 0.6 & 0.7 & 0.9 & 0.4 & 0.8 & 0.6 & 0.8 & 0.4 & 0.6 \\
\hline
\end{tabular}

${ }^{\text {a }}$ Relative to $\mathrm{C}_{9}-\mathrm{C}_{17}$ n-alkanes on a DB-1 column.

b Identification based on mass spectra only.

${ }^{c} \mathrm{t}=\operatorname{trace}(<0.05 \%)$. 


\section{Euclidean Distance}

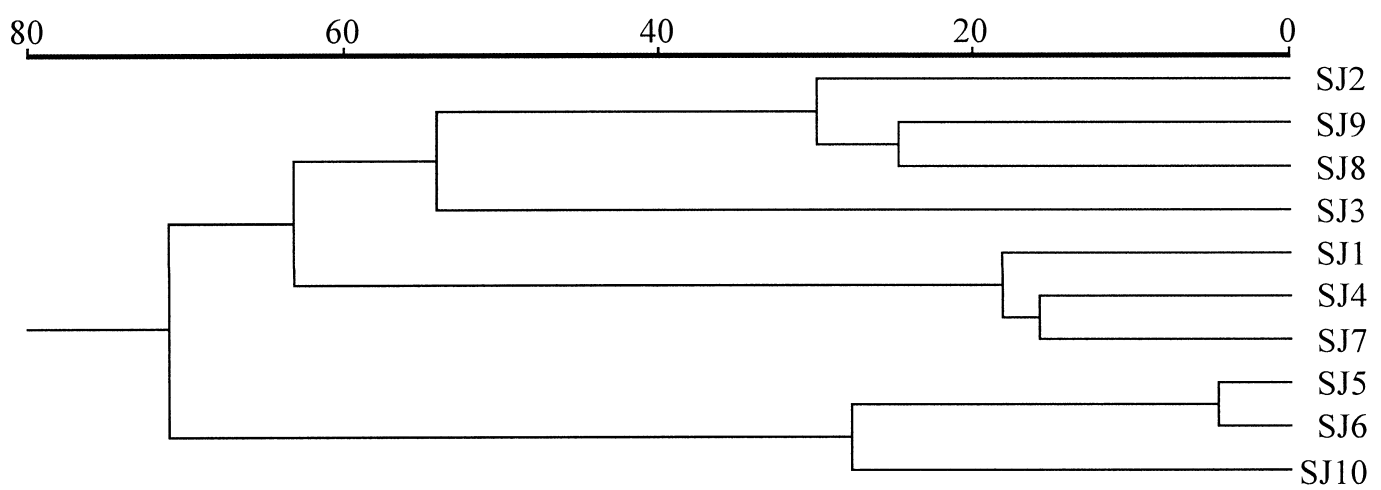

Fig. 2. Dendrogram obtained by cluster analysis of the percentage composition of essential oils from ten populations of Thymus caespititius, based on Euclidean distance and using the unweighed pair-group method with arithmetic average (UPGMA).

oils from the populations SJ1-SJ4, collected at Pico Verde, changed remarkably, as one of the populations, i.e. number SJ2, showed a much higher carvacrol content (52\%) than each of the four populations studied in 1998 - with $12 \%$ as the highest percentage of carvacrol (Pereira et al., 1999b). Although we are working with collective samples, the differences recorded seem to support the occurrence of a high genetic variability of the populations growing on Pico Verde. Moreover, since Th. caespititius is the only representative of the genus on the island, the variability observed cannot result from an interbreeding between Th. caespititius and other species from this genus.

Being aware of this chemical variability, a morphological study was performed, by scanning electron microscopy, on the indumentum of two distinct populations of Pico Verde. Despite the differences in essential oil composition, the two populations showed similar types of non-glandular and glandular trichomes, and an identical distribution of these trichomes, both on the vegetative and reproductive organs (leaf, calyx, petiole, corolla, ovary and anther) (Pereira et al., 1999c).

Of the chiral compounds present in the monoterpene fraction of the essential oils, only sabinene and $\alpha$-terpineol were investigated for their enantiomeric ratio, due to their high concentration in the oil samples from some populations. (+)-Sabinene was detected with high enantiomeric purity in the oils from populations $\mathrm{SJ} 3$ and SJ4 (99 and 96\%, respectively) (Table 2). Although $(+)-\alpha$-terpineol was the predominant enantiomer in the oils from all the populations investigated, its purity varied considerably, ranging from 92 to $97 \%$ in the oils from populations SJS-SJ7 and SJ10 and attaining only 66 and $86 \%$ in those from populations SJ8 and SJ9, respectively (Table 2 ).

Several factors, other than the genetic determination, have been reported to influence the essential oil composition in general, and the content of certain constituents in particular (Figueiredo et al., 1997). According to data
Table 2

Enantiomeric percentage composition of sabinene and $\alpha$-terpineol in the essential oils from populations of Thymus caespititius grown on $\mathrm{S}$. Jorge

\begin{tabular}{lrrrrrrrr}
\hline Components & \multicolumn{9}{l}{ Populations } & & & & & \\
\cline { 2 - 8 } & SJ3 & SJ4 & SJ5 & SJ6 & SJ7 & SJ8 & SJ9 & SJ10 \\
\hline (-)-Sabinene & 1.3 & 4.5 & & & & & & \\
(+)-Sabinene & 98.7 & 95.5 & & & & & & \\
$(-)-\alpha$-Terpineol & & & 2.8 & 2.9 & 3.0 & 34.0 & 14.4 & 7.7 \\
$(+)-\alpha$-Terpineol & & & 97.2 & 97.1 & 97.0 & 66.0 & 85.6 & 92.3 \\
\hline
\end{tabular}

reported for Th. vulgaris (Gouyon et al., 1986) and Th. piperella (Boira and Blanquer, 1998) the phenol content of the essential oils, for instance, is influenced by environmental factors such as humidity and temperature.

Since S. Jorge is a small island, ca. $246 \mathrm{~km}^{2}$, possessing a quite uniform climate, it seems unlikely that the fluctuations of humidity and temperature are strong enough to induce the high chemical variability recorded, particularly that among the populations SJ1-SJ4. The same holds true for altitude variation, since no correlation could be established between the altitudes of the collection sites and the chemical compositions of the oils.

Edaphic factors such as the chemical composition of the soil, namely the content of $\mathrm{CO}_{3}^{2-}$, have also been found to influence the essential oil composition of Thymus species (Gouyon et al., 1986; Martónfi et al., 1994). The influence of these factors on the compositions of the essential oils obtained from the populations grown on $\mathrm{S}$. Jorge should be taken into account due to the volcanic origin of the island. Apart from the fact that volcanic rocks make some of the best soils, since their composition includes a high variety of chemical elements readily available to be taken up by plants, different materials are expelled during a volcanic eruption, leading to the formation of different soil types in a very narrow area. 
In conclusion, the essential oil from Th. caespititius grown on S. Jorge shows a high chemical polymorphism, particularly evident in the populations SJ1-SJ4. Since the glandular structures of the plants in question are morphologically similar, and neither the climate nor the altitude variations can explain the chemical variability observed, it seems likely that this polymorphism results either from the genetic variability of the populations or from the influence of edaphic factors.

\section{Experimental}

\subsection{Plant material}

Aerial parts of Th. caespititius were collected during the full flowering period of the plant (June 1999) from ten populations growing in seven different places on S. Jorge (Azores): Pico Verde (populations SJ1-SJ4); Cume dos Arrebentões (population SJ5); Serra do Topo (population SJ6); Farol dos Rosais (population SJ7); Ponta do Topo (population SJ8); Pico da Ponta Furada (population SJ9); Fajã de S. João (population SJ10). A voucher specimen of each population has been deposited in the Herbarium of the Museu, Laboratório e Jardim Botânico de Lisboa (population SJ1, LISU: 171,726; population SJ2, LISU: 171,727; population SJ3, LISU: 171,724; population SJ4, LISU: 171725; population SJ5, LISU: 171,728; population SJ6, LISU: 171,723; population SJ7, LISU: 171,720; population SJ8, LISU: 171,717; population SJ9, LISU: 171,722; population SJ10, LISU: 171,729).

\subsection{Isolation procedure}

The essential oils were isolated from deep-frozen $\left(-20^{\circ} \mathrm{C}\right)$ plant material by distillation-extraction for $3 \mathrm{~h}$, using a Likens-Nickerson-type apparatus (Likens and Nickerson, 1964) with $n$-pentane as organic solvent, and by hydrodistillation for $3 \mathrm{~h}$, using a Clevenger-type apparatus (Anonymous, 1996). The oil samples isolated by hydrodistillation were used to estimate the oil yields, and those isolated by distillation-extraction to determine their percentage composition.

\subsection{Gas chromatography}

GC analyses were performed using a twin FID instrument, a data handling system and a vaporizing injector port into which two columns of different polarities were installed: a DB-1 fused-silica column $(30 \mathrm{~m} \times 0.25 \mathrm{~mm}$ i.d., film thickness $0.25 \mu \mathrm{m}$ ) and a DB-17HT fused-silica column $(30 \mathrm{~m} \times 0.25 \mathrm{~mm}$ i.d., film thickness $0.15 \mu \mathrm{m})$. The oven temp. was programmed, $45-175^{\circ} \mathrm{C}$ at $3^{\circ} \mathrm{C} \mathrm{min}{ }^{-1}$, subsequently at $15^{\circ} \mathrm{C} \mathrm{m^{-1 }}$ up to $300^{\circ} \mathrm{C}$ and then held isothermally for $10 \mathrm{~min}$; injector and detector temps were 280 and $290^{\circ} \mathrm{C}$ respectively; carrier gas, $\mathrm{H}_{2}$ at $30 \mathrm{~cm} \mathrm{~s}^{-1}$.
GC chiral analyses were performed using an FID instrument, a data handling system and a CyclosilB fused-silica column $(30 \mathrm{~m} \times 0.25 \mathrm{~mm}$ i.d., film thickness $0.25 \mu \mathrm{m})$. Oven temp. was $75^{\circ} \mathrm{C}$ isothermal, for sabinene, and $105^{\circ} \mathrm{C}$ isothermal, for $\alpha$-terpineol; injector and detector temps, 280 and $290^{\circ} \mathrm{C}$, respectively; carrier gas, $\mathrm{H}_{2}$ at $42 \mathrm{~cm} \mathrm{~s}^{-1}$.

In the chiral analyses, the hydrocarbon fraction of the oil samples was separated from the oxygen-containing components on a Sep-Pak silica column and authentic samples of sabinene and $\alpha$-terpineol enantiomers were used for comparison.

Samples were injected using the split-sampling technique with a ratio of 1:50. Percentage composition of oils was computed using the normalization method from the GC peak areas without correction factors. Percentage data shown are mean values of two injections of each oil sample.

\subsection{Gas chromatography-mass spectrometry}

The GC-MS unit was equipped with a DB-1 fusedsilica column $(30 \mathrm{~m} \times 0.25 \mathrm{~mm}$ i.d., film thickness 0.25 $\mu \mathrm{m})$ and interfaced with an ion trap detector (ITD; software version 4.1). Oven temp. was as described above; transfer line temp., $280^{\circ} \mathrm{C}$; ion trap temp., $220^{\circ} \mathrm{C}$ carrier gas, He at $30 \mathrm{~cm} \mathrm{~s}^{-1}$; split ratio, 1:40; ionization energy, $70 \mathrm{eV}$; ionization current, $60 \mu \mathrm{A}$; scan range, 40 $300 \mathrm{u}$; scan time, 1s. The identity of the components was assigned by comparison of their RIs, relative to $\mathrm{C}_{9}-\mathrm{C}_{17}$ $n$-alkanes, and MS with corresponding data of components of reference oils or of synthetic compounds.

\subsection{Cluster analysis}

The percentage composition of the essential oil samples was used to determine the relationship between the different populations of Th. caespititius by cluster analysis using the NTSYS software (Rohlf, 1992). Euclidean distance was selected as a measure of similarity, and the unweighed pair-group method with arithmetic average (UPGMA) was used for cluster definition.

\section{Acknowledgements}

This study was funded by the Fundaçâo para a Ciência e Tecnologia (FCT), Lisbon, under research contract no Praxis/P/BIA/11054/98.

\section{References}

Anonymous, 1996. European Pharmacopoeia, 3rd Edition. Council of Europe, Strasbourg, pp. 121-122.

Boira, H., Blanquer, A., 1998. Environmental factors affecting chemical variability of essential oils in Thymus piperella L. Biochemical Systematics and Ecology 26, 811-822. 
Fernandes Costa, A., 1945. Espécies peninsulares do género Thymus L. Boletim da Escola de Farmácia da Universidade de Coimbra 5, 97-134.

Fernandes Costa, A., 1975. Elementos da Flora Aromática. Junta de Investigações Científicas do Ultramar, Lisbon, pp. 118-122.

Figueiredo, A.C., Barroso, J.G., Pedro, L.G., Scheffer, J.J.C., 1997. Physiological aspects of essential oil production. In: Franz, Ch., Máthé, Á, Buchbauer, G. (Eds.), Essential Oils: Basic and Applied Research. Allured Publishing Corp, Carol Stream, IL, pp. 95-107.

Gouyon, P.H., Vernet, Ph., Guillerm, J.L., Valdeyron, G., 1986. Polymorphisms and environment: the adaptive value of the oil polymorphisms in Thymus vulgaris L. Heredity 57, 59-66.

Likens, S.T., Nickerson, G.B., 1964. Detection of certain hop oil constituents in brewing products. American Society of Brewing Chemists, Proceedings, pp. 5-13

Mártonfi, P., Grejtovský, A., Repcák, M., 1994. Chemotype pattern differentiation of Thymus pulegioides on different substrates. Biochemical Systematics and Ecology 22, 819-825.

Pena, A., Cabral, J., 1997. Roteiros da Natureza - Regiâo Autónoma dos Açores. Temas e Debates, Lisbon.

Pereira, S.I., Santos, P.A.G., Barroso, J.G., Figueiredo, A.C., Pedro, L.G., Salgueiro, L.R., Deans, S.G., Scheffer, J.J.C. 1999a. Composição do óleo essencial de duas populações de Thymus caespititius Brot. do Faial. In: I Congresso das Plantas Aromáticas e
Medicinais dos Países de Língua Oficial Portuguesa, Conimbriga Ansião, Portugal, p. 41 (abstract).

Pereira, S.I., Santos, P.A.G., Barroso, J.G., Pedro, L.G., Figueiredo, A.C., Salgueiro, L.R., Deans, S.G., Scheffer, J.J.C. 1999b. Composition of the essential oils from thirteen populations of Thymus caespititius Brot. grown on the island S. Jorge (Azores). In: 30th International Symposium on Essential Oils, Leipzig, p. B-08 (abstract).

Pereira, S.I., Santos, P.A.G., Barroso, J.G., Pedro, L.G., Figueiredo, A.C., Salgueiro, L.R., Deans, S.G., Scheffer, J.J.C. 1999c. Morfologia e distribuição de tricomas glandulares e composiçâo do óleo essencial de trés populações de Thymus caespititius Brot. dos Açores. In: XXXIV Reunião Anual da Sociedade Portuguesa de Microscopia Electrónica e Biologia Celular, Lisbon, p. 63 (abstract).

Rohlf, J.F., 1992. NTSYS-pc, Numerical Taxonomy and Multivariate Analysis System. Applied Biostatistics Inc, New York.

Salgueiro, L.R., 1994. Os tomilhos Portugueses e os seus óleos essenciais. PhD thesis, Vol. 1. Faculty of Pharmacy, University of Coimbra.

Salgueiro, L.R., Vila, R., Tomi, F., Figueiredo, A.C., Barroso, J.G., Cañigueral, S., Caranova, J., Cunha, A.P., Adzet, T., 1997. Variability of essential oils of Thymus caespititius from Portugal. Phytochemistry 45, 307-311.

Sjögren, E., 1984. Açores - Flores. Direcção Regional de Turismo. Horta, Faial. 